NBER WORKING PAPER SERIES

\begin{abstract}
MONETARY POLICY REGIMES, EXPECTED INFLATION, AND THE RESPONSE OF INTEREST RATES TO MONEY ANNOUNCEMENTS
\end{abstract}

V. Vance Roley

Car1 E. Walsh

Working Paper No. 1181

NATIONAL BUREAU OF ECONOMIC RESEARCH

1050 Massachusetts Avenue

Cambridge, MA 02138

August 1983

The research reported here is part of the NBER's research program in Financial Markets and Monetary Economics. Any opinions expressed are those of the authors and not those of the National Bureau of Economic Research. 
Monetary Policy Regimes, Expected Inflation, and the Response of Interest Rates to Money Announcements

\title{
ABSTRACT
}

This paper examines the response of the term structure of interest rates to weekly money announcements. Estimated responses for both the pre- and post-October 1979 periods are first presented. Then, two competing hypotheses involving the policy anticipations and expected inflation effects are formally specified and compared to the estimated responses. Both hypotheses are found to be consistent with the responses, but they have sharply different implications about the Federal Reserve's shortrun monetary policy. The expected inflation hypothesis implies that weekly money surprises should have persistent effects on the level of the money stock, reflecting shifts in the Federal Reserve's long-run target. In contrast, the policy anticipations hypothesis implies that the effect of money surprises should diminish over time, reflecting the Federal Reserve's desire to offset deviations from target. Additional empirical results reported in the paper support this latter description of the money stock process.

\author{
V. Vance Roley \\ Department of Finance DJ-10 \\ University of Washington \\ Seattle, WA 98195 \\ (206) $545-7476$ \\ Car1 E. Walsh \\ Department of Economics \\ Princeton University \\ Princeton, NJ 08544 \\ (609) 452-4026
}

Graduate School of Business Administration 


\section{MONETARY POLICY REGIMES, EXPECTED INFLATION, AND THE RESPONSE OF INTEREST RATES}

TO MONEY ANNOUNCEMENTS

V. Vance Roley and Car1 E. Walsh*

Recent studies on the response of interest rates to weekly money announcements reveal several interesting empirical relationships. First, the empirical results of Berkman (1978), Grossman (1981), and Urich and Wachtel (1981) indicate that Treasury bill yields rise (fall) in response to an unanticipated increase (decrease) in the announced money stock. $1 /$ Second, Roley (1982, 1983) and Cornell (1983) find that the magnitude of the bill-yield response increased following the Federal Reserve's announced change in operating procedures on October 6, 1979. Third, Cornell (1983) estimates significant positive responses for long-term yields in both the pre- and post-0ctober 1979 periods, with a significantly larger response in the post-0ctober 1979 period.

These empirical results are of interest not only because of the magnitude of the interest-rate fluctuations associated with unanticipated announced changes in money, but also because the estimated responses potentially provide evidence on the short-run monetary policy rule describing Federal Reserve behavior. In particular, under rational expectations, the market's response depends importantly on the Federal Reserve's desire to of in money from its target. The empirical evidence, however, appears to be consistent with two different hypotheses about the Federal Reserve's desire to control money as well as the information content of weekly money announcements.

One hypothesis relies on studies by Fama (1975) and Nelson and Schwert (1977), among others, who estimate that changes in expected inflation account for most of the fluctuations in nominal interest rates. 2 / Under this hypothesis, 
a positive surprise in a weekly money announcement that is not expected to be offset totally by the Federal Reserve leads to an increase in expected inflation. Thus, the increased interest-rate response following the change in operating procedures in October 1979 is interpreted as evidence that the Federal Reserve is less committed to monetary control. Moreover, the significant response of long-term interest rates in both the pre- and post-October 1979 periods is interpreted as reflecting changes only in expected inflation [e.g., Cornell (1983) and Hardouvelis (1982)].

The other hypothesis is based on a policy anticipations effect. Under this hypothesis, market participants are assumed not to revise their expectation about future inflation on the basis of any one-week's money surprise. Instead, the Federal Reserve is assumed to offset at least partially any deviation in money from its target. A positive money surprise would then imply a rise in expected future interest rates in anticipation of policy actions designed to bring the money stock back to target. This paradigm, therefore, suggests that real interest rates change in response to unanticipated announced changes in money. Thus, in contrast to the expected inflation hypothesis, the increased interest-rate response after October 1979 is consistent with a greater desire by the Federal Reserve to control money along with other possible effects related more closely to the change in operating procedures itself [e.g., Roley (1982, 1983) and Walsh (1983)]. Evidence supporting the policy anticipations hypothesis is presented by Cornell (1982) and Engel and Frankel (1982) who find, in the context of the foreign exchange market, that the dollar appreciates in response to a positive surprise in announced money. $3 /$ However, both Cornell 
(1983) and Hardouvelis (1982) claim that the response of long-term interest rates is too large to be explained by this effect.

The purpose of this paper is to specify separate models consistent with the policy anticipations and expected inflation effects, respectively, and to compare their implications for interest rate responses over the entire term structure. The increased response of interest rates after October 1979 and the relatively large response of long-term rates are shown to be consistent with the policy anticipations effect. In particular, these phenomena can be explained by the Federal Reserve's change in operating procedures, the degree of short-run monetary control, and the persistence of money demand shocks. Other models of the policy anticipations effect do not include long-term interest rates, and they selectively ignore such important institutional features as the type of operating procedures used by the Federal Reserve, lagged reserve accounting, and the $\mathrm{lag}$ in money announcements [e.g., Urich (1982) and Nichols, Small, and Webster (1983)]. This institutional detail plays a key role in the models considered here.

In the first section of this paper, the response of the term structure of interest rates in the pre- and post-0ctober 1979 periods is estimated. The policy anticipations and the expected inflation models are presented in the second and third sections, respectively. In the fourth section, the empirical results are reconciled with the predictions of both models, and additional empirical evidence on the relative merits of the two models is discussed. The main conclusions are summarized in the final section.

\section{Estimated Response of Interest Rates}

In this section, the response of the term structure of interest rates in the pre- and post-october 1979 periods is estimated. The empirical results 
exhibit both the increase responsiveness since October 1979 and the relatively large response of long-term yields. These results are presented following brief discussions of the specification and data used in the estimation.

\section{Specification}

The usual efficient markets approach is adopted to estimate the response of interest rates to weekly money announcements. To conform with the theoretical models presented in subsequent sections, the consequences of the efficient markets hypothesis may be represented as

$$
\Delta R_{t}=b_{0}+b_{1} \cdot\left(\operatorname{lnM}_{t}-1 n M_{t}^{e}\right)+e_{t}
$$
where $\Delta \mathrm{R}_{t}=\begin{aligned} & \text { change in the interest rate over a time interval including the } \\ & \text { money stock announcement in week } t\end{aligned}$

$M_{t}=$ announced level of the money stock in week $t$

$\mathrm{M}_{t}^{\mathrm{e}}=$ market's rational expectation of the announced level of the money stock in week $t$

$e_{t}=$ random error term uncorrelated with any information available to the public prior to the money announcement in week $t$

$\mathrm{b}_{0}, \mathrm{~b}_{1}=$ estimated coefficients

While a constant term is always included in the empirical specifications, it should equal zero under the null hypothesis of market efficiency and in the absence of systematic measurement error.

\section{Data}

All of the data described below are weekly and span the period beginning on September 29, 1977 and ending on October 15, 1982. The last observation of the pre-0ctober 1979 subsample falls on October 5, 1979. Observations were excluded if either discount rate changes or announcements of other relevant economic data were made within the time interval corresponding to the measured change in interest rates. 4 / 
The money stock data consist of announced weekly levels of the narrowly defined money stock, in billions of dollars, as reported in the Federal Reserve's H.6 release. From the beginning of the sample through January 31, 1980, the data correspond to "old Ml," and weekly announcements were made on Thursday. From February 8, 1980, through October 15, 1982, announcements were made on Friday. For this period, the data employed are those for M1-B, and more recently, MI, where the definition of this latter aggregate is equivalent to that of $M 1-B . \underline{5} /$

Data for the expected announced level of the money stock are based on the survey data compiled by Money Market Services, Inc. The survey data represent the market's expected announced change in the money stock. To construct expected levels, market participants are assumed to expect no revision in the previous week's announced level. 6 / The survey data begins on September 29, 1977. Prior to February 8, 1980, the median of the Thursday survey is used to represent the market's anticipated money announcement on each Thursday. For the remainder of the sample, the survey was conducted on Tuesday for the Friday announcement. Because of this misalignment, a revised expectation reflecting the availability of new information from Tuesday to Friday is used. $\underline{\text { I }}$

The yield data are taken from the H.15 release, published by the Federal Reserve. All data are in terms of coupon-equivalent yields, in percent, and quoted bids are used. The change in interest rates is measured from $3: 30 \mathrm{p} . \mathrm{m}$. on the day of a money announcement to $3: 30 \mathrm{p} \cdot \mathrm{m}$. on the following business day. Thus, any effect of money announcements-which are made at 4:10 p.m.- should be reflected in the measured change in yields. $\underline{8}$ / 


\section{Empirical Results}

Estimation results of the efficient markets model ( 1 ) over the preand post-october 1979 subsamples are presented in Table 1. $\frac{9}{}$ within each subsample, the estimated response of Treasury security yields declines, with one exception, as maturity increases. In the pre-0ctober 1979 subsample, for example, the 3-month Treasury bill yield is estimated to increase by about $61 / 2$ basis points for a 1 percent announced money surprise, while the 20-year yield increases by about 1 basis point. Similarly, in the post-October 1979 subsample, the 3-month yield's response is over $21 / 2$ times greater than that of the 20-year yield. Despite the lower estimated response of long-term yields, Cornell (1983) and Hardouvelis (1982) suggest that the response is nevertheless too large to be explained by the policy anticipations effect, especially in the post-October 1979 period. Instead, the expected inflation effect is hypothesized to account for the response of long-term yields.

The empirical results in Table 1 also indicate that the estimated response for all maturities of Treasury securities is over five times larger in the postOctober 1979 period. In the last column, the equality of the response is formally tested, and in each case the null hypothesis can be rejected at less than the 1 percent level of significance. $10 /$ As mentioned earlier, these results are apparently consistent with two competing hypotheses. First, the response may have increased because of the change in Federal Reserve operating procedures and perhaps a somewhat greater commitment to monetary control [Roley $(1982,1983)$ and Walsh (1983)]. Second, the larger response may ref lect less desire to control money, implying larger changes in expected inflation for a given money surprise [Cornell (1983) and Hardouvelis (1982)]. These empirical results are discussed further in the fourth section in the context of the two competing hypotheses. 
Table 1

RESPONSE OF INTEREST RATES TO

MONEY ANNOUNCEMENT SURPRISES

$$
\Delta R_{t}=b_{0}+b_{1} \cdot U M_{t}+e_{t}
$$

\begin{tabular}{|c|c|c|c|c|c|c|c|c|c|}
\hline \multirow[b]{2}{*}{ Yield } & \multicolumn{4}{|c|}{ Pre-October $1979 \dagger$} & \multicolumn{4}{|c|}{ Post-October $1979 \dagger$} & \multirow{2}{*}{$\frac{\mathrm{H}_{0}: \mathrm{b}_{1}=\mathrm{b}_{1}{ }^{\prime}}{\mathrm{F}(1,194)^{5}}$} \\
\hline & $\mathrm{b}_{0}$ & $\mathrm{~b}_{1}$ & $\overline{\mathrm{R}}^{2}$ & $S E$ & $\mathrm{~b}_{0}{ }^{\prime}$ & $\mathrm{b}_{1}{ }^{-}$ & $\overline{\mathrm{R}}^{2}$ & $S \bar{E}$ & \\
\hline $\mathrm{RFF}$ & $\begin{array}{l}.0036 \\
(.0128)\end{array}$ & $\begin{array}{c}.4216 \\
(2.890)\end{array}$ & -.02 & 1009 & $\begin{array}{l}.0516 \\
(.0570)\end{array}$ & $\begin{array}{l}43.31^{*} \\
(10.37)\end{array}$ & .11 & .6605 & 15.86 \\
\hline$R I W$ & $\frac{.0501}{(.0222)}$ & $\begin{array}{c}4.686 \\
(5.017)\end{array}$ & -.00 & .1752 & $\begin{array}{l}.2146^{*} \\
(.0509)\end{array}$ & $\begin{array}{c}36.72^{*} \\
(9.253)\end{array}$ & .10 & .5891 & 9.26 \\
\hline R3M & $\begin{array}{l}.0121 \\
(.0136)\end{array}$ & $\begin{array}{c}6.478^{\star} \\
(3.065)\end{array}$ & .05 & .1070 & $\begin{array}{c}.0567 \\
(.0332)\end{array}$ & $\begin{array}{c}36.40^{*} \\
(6.046)\end{array}$ & .21 & .3847 & 19.48 \\
\hline RIY & $\begin{array}{l}.0087 \\
(.0079)\end{array}$ & $\begin{array}{c}5.199^{*} \\
(1.789)\end{array}$ & .11 & .0625 & $\begin{array}{l}.0279 \\
(.0259)\end{array}$ & $\begin{array}{l}35.54^{*} \\
(4.719)\end{array}$ & .29 & .3005 & 36.14 \\
\hline R5Y & $\begin{array}{c}.0031 \\
(.0041)\end{array}$ & $\begin{array}{l}2.574^{*} \\
(.9322)\end{array}$ & .10 & .0326 & $\begin{array}{l}.0397^{\star} \\
(.0179)\end{array}$ & $\begin{array}{c}21.23^{\star} \\
(3.257)\end{array}$ & .24 & .2074 & 30.34 \\
\hline R10Y & $\begin{array}{l}.0067 \\
(.0042)\end{array}$ & $\begin{array}{c}.9197 \\
(.9495)\end{array}$ & -.00 & .0332 & $\begin{array}{l}.0381^{*} \\
(.0156)\end{array}$ & $\begin{array}{c}16.08^{*} \\
(2.834)\end{array}$ & .19 & .1804 & 25.74 \\
\hline R2OY & $\begin{array}{l}.0036 \\
(.0030)\end{array}$ & $\begin{array}{c}1.161 \\
(.6809)\end{array}$ & .03 & .0238 & $\begin{array}{l}.0367^{\star} \\
(.0157)\end{array}$ & $\begin{array}{l}14.41^{\star} \\
(2.847)\end{array}$ & .16 & .1812 & 20.50 \\
\hline
\end{tabular}

*Significant at 5 percent level.

the pre-October 1979 subsample begins on September 29, 1977 and ends on October 5, 1979. The post-October 1979 subsample begins on October 8, 1979 and ends on October 15, 1982. Standard errors of estimated coefficients are in parentheses.

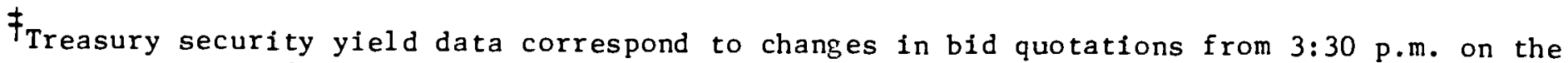
announcement day to $3: 30 \mathrm{p} . \mathrm{m}$. on the following business day. Federal funds rate data are daily averaged yields. (Source: Board of Governors of the Federal Reserve System, H.15.)

S In each test, the null hypothesis can be rejected at less than the 1 percent level of significance.

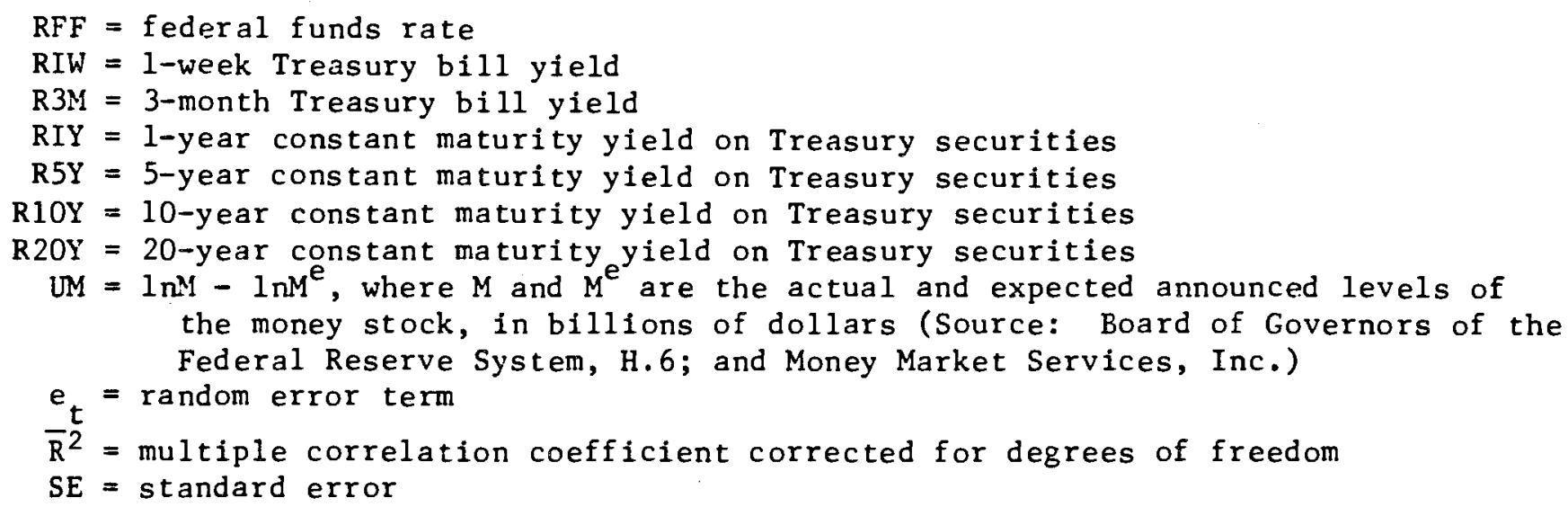




\section{Policy Anticipations Model}

In this section, a model of the response of interest rates to money announcements is developed which focuses exclusively on the policy anticipations effect. By ignoring the role of expected inflation, it will be possible to determine whether the policy anticipations explanation is, in isolation, consistent with the empirical results reported in Table 1 . of particular interest is the ability of the model to explain the response of long-term interest rates as well as the increased response of all rates in the post-October 1979 period. Because institutional features are important for a complete understanding of the policy anticipations effect, it will be useful to begin with an overview of the Federal Reserve's policy procedures before turning to the formal model.

The money stock figure released at 4:10 p.m. on Fridays is the Federal Reserve's current estimate of the money stock during the settlement week ending nine days previously. This has two important implications. First, because of lagged reserve accounting, the Friday announcement provides market participants with an estimate of the deposit levels against which required reserves for the current settlement week are levied. Second, because money demand shifts cause week to week movements in the quantity of money, the announcement provides information on any money demand shift which may have occurred two weeks previously. 11 /

In estimating the money stock prior to the Friday announcement, the Federal Reserve may adjust its target path for the monetary aggregates in light of any deviation of actual money from target. Under lagged reserve accounting, monetary policy is implemented by using a policy instrument- 
the federal funds rate in the pre-0ctober 1979 period and nonborrowed reserves in the post-October 1979 period-in an attempt to make money demand equal to the targeted quantity of money. While the direct effects of Federal Reserve actions are to influence the federal funds rate, this is not the interest rate most relevant for the demand for money. The Federal Reserve must, therefore, estimate what change in the funds rate will lead to changes in other short-term rates which, in turn, will produce the desired effect on the demand for money. Any model of the policy anticipations effect needs, therefore, to specify: 1) the informational content of the money announcement and how it depends on the operating procedures of the Federal Reserve; 2) the determinants of the demand for money; 3) the linkages between variables influencing money demand and the Federal Reserve's policy instruments; 4) the operating procedures followed by the Federal Reserve in attempting to achieve its monetary targets; and 5) the manner in which the target path for money is adjusted in light of deviations between the actual quantity of money and the target path.

Within this conceptual framework, consider the actions of the Federal Reserve at the beginning of settlement week $t$. Assume, for simplicity, that in setting its policy instrument for week $t$, the Federal Reserve, but not yet the public, knows $m_{t-2}$, the (log) money supply during week $t-2$. This is the number which will be announced on Friday of week $t$. The Federal Reserve cannot yet observe $m_{t-1}$, but on the basis of $m_{t-2}$ (and perhaps other information), an estimate of week t-1's deviation from target, $E\left(m_{t-1} \mid \Omega_{t}\right)-m_{t-1}^{T}\left(\Omega_{t-1}\right)$, is formed, where $\Omega_{t}$ denotes the Federal Reserve's information set at the start of week $t, E\left(m_{t-1} \mid \Omega_{t}\right)$ is the expectation of $m_{t-1}$ conditional on $\Omega_{t}$, and 
$m_{t-1}^{T}\left(\Omega_{t-1}\right)$ is the target value for $m_{t-1}$ which had been set at the start of week $t-1$ based on $\Omega_{t-1}$. The estimate of this deviation is used to revise the target path. The policy rule is assumed to be,

$$
\begin{aligned}
\mathrm{m}_{t+j}^{\mathrm{T}}\left(\Omega_{t}\right)-\mathrm{m}_{t+j}^{\mathrm{T}}\left(\Omega_{t-1}\right)= & {\left[\delta_{1}+(1-\lambda)^{j+1}\left(1-\delta_{1}\right)\right] } \\
& \cdot\left[E\left(\mathrm{~m}_{t-1} \mid \Omega_{t}\right)-\mathrm{m}_{t-1}^{\mathrm{T}}\left(\delta_{t-1}\right)\right] ; j=0,1, \ldots
\end{aligned}
$$

According to (2), a deviation from target during week $t-1$ leads to a revised target path for money for all future weeks. Equation (2) implies that the Federal Reserve plans to offset eventually a fraction $\left(1-\delta_{1}\right)$ of the week $t-1$ deviation from target. It does so only gradually, however, at the rate $(1-\lambda)$ per week. The remaining fraction of the deviation, $\delta_{1}$, is not offset. $12 /$ If $\delta_{1}=0$, the new path $\left[\mathrm{m}_{t+j}^{\mathrm{T}}\left(\Omega_{t}\right)\right]$ returns to the old path $\left[\mathrm{m}_{t+j}^{\mathrm{T}}\left(\Omega_{t-1}\right)\right]$ as $j \rightarrow \infty$. Because this section treats expected inflation as constant in order to emphasize the policy anticipations effect, equation (2) implicitly assumes that the Federal Reserve does not revise its targeted long-run growth rate for the money supply.

The Federal Reserve has two potential policy instruments: the weekly average federal funds rate, $i_{t}$, or the weekly average path of (log) nonborrowed reserves, $1 \operatorname{lnNBR}_{t} .13 /$ Dealing first with the pre-October 6, 1979 period, $i_{t}$ will initially be treated as the tool used to implement policy.

\section{Pre-October 1979 Operating Procedures}

Prior to October 1979, the Federal Reserve used $i_{t}$ in trying to equate money demand to the targeted quantity of money. It is assumed that money demand is given by

$$
m_{t}-p_{t}=\alpha_{0}-\alpha r_{t}+u_{t}
$$


where $P_{t}$ is the log of the price level and $r_{t}$ is the rate on an $n$-week security, such as a 13-week Treasury bill. The appearance of $r_{t}$ in (3) captures the notion that the demand for money does not depend on the federal funds rate, but on a longer term interest rate. Income is treated as a constant for this analysis and is not explicitly included in (3). Since, in this section, $P_{t}$ will be treated as a constant, it will be covenient to define $\alpha_{0}^{\prime}=\alpha_{0}+p_{t}$ and write

$$
m_{t}=\alpha_{0}^{\prime}-\alpha_{1} r_{t}+u_{t}
$$

As $\left(3^{-}\right)$is a weekly money demand equation, the random disturbance $u_{t}$ is likely to exhibit a high degree of serial correlation. $14 /$ To model this in a simple way, assume

$$
u_{t}=\rho u_{t-1}+\varepsilon_{t},|\rho|<1
$$

where $\varepsilon_{t}$ is a white noise process.

An expectations model of the term structure of interest rates is used to link $i_{t}$ and $r_{t}$. If $\Phi_{t}$ is defined as the information set available to the public,

$$
r_{t}=(1 / n) \sum_{j=0}^{n-1} E\left(i_{t+j} \mid \Phi_{t}\right) .
$$

Equation (5) reveals why current interest rates such as $r_{t}$ will depend on anticipated future policy since $r_{t}$ is a function of expected future settings of the policy variable $i_{t}$.

Using the money demand function $\left(3^{\circ}\right)$, the Federal Reserve can calculate the path of $r_{t}$ which is consistent with its target path for the money stock, conditional on the information available at the beginning of week $t$. If $r_{t+i}^{T}\left(\Omega_{t}\right)$ is this target path, suppose $i_{t+i}^{T}\left(\Omega_{t}\right)$ is the path for the federal funds rate which satisfies: 


$$
r_{t+i}^{T}\left(\Omega_{t}\right)=(1 / n) \sum_{j=0}^{n-1} i_{t+i+j}^{T}\left(\Omega_{t}\right) ; i=0, \ldots
$$

Because of idiosyncratic developments during week $t$, assume the funds rate actually set by the Federal Reserve is given by

$$
i_{t}=i_{t}^{T}\left(\Omega_{t}\right)+\theta_{t}
$$

where $\theta_{t}$ is a mean zero, serially uncorrelated weekly policy deviation from the targeted value of the funds rate.

With a funds rate operating procedure, the Federal Reserve sets $i_{t}$ according to (7) at the beginning of the settlement week. Because $i_{t}^{T}\left(s_{t}\right)$ is based on $\Omega_{t}$ which includes information not available to the public prior to the Friday announcement, the public cannot distinguish the component parts in (7). Using the term structure equation (5), the appendix shows that $r_{t}$ can be written as

$$
\begin{aligned}
r_{t}= & (1 / n) i_{t}-\alpha^{-1} \sum_{j=0}^{\infty} E\left(m_{t+j n+1}^{T}-m_{t+j n+n}^{T} \mid \Phi_{t}\right) \\
& +\alpha^{-1} \sum_{j=0}^{\infty} E\left(u_{t+j n+1}-u_{t+j n+n} \mid \Phi_{t}\right)+\frac{n-1}{n} E\left(r_{t+\infty}^{T} \mid \Phi_{t}\right)
\end{aligned}
$$

Equation (8) shows explicitly how $r_{t}$ depends on the public's expectations about the target path for the money supply.

In order to analyze the effects of the money announcement, it will be necessary to define more specifically the public's information set $\Phi_{t}$ and relate it to the Federal Reserve's information set $\Omega_{t}$. Let $\Phi_{t}^{b}$ denote the public's information prior to the money announcement. Let $r_{t}^{b}$ be the equilibrium value of $r_{t}$, just prior to the announcement, obtained by substituting $\Phi_{t}^{b}$ for $\Phi_{t}$ in (8). Similarly, define $\Phi_{t}^{a}=\left\{m_{t-2}, \Phi_{t}^{b}\right\}$ as the public's information set after 
$\mathrm{m}_{\mathrm{t}-2}$ is announced. The interest rate after the announcement is $\mathrm{r}_{\mathrm{t}}^{\mathrm{a}}$. Since the only new information analyzed here is the announcement of $m_{t-2}$, it follows that $\Phi_{t}^{b}=\Omega_{t-1} C \Omega_{t}=\Phi_{t}^{a}$.

From (3-), $m_{t-2}=\alpha_{0}^{j}-\alpha r_{t-2}+u_{t-2}$ so that prior to the announcement, $E\left(m_{t-2} \mid \Phi_{t}^{b}\right)=\alpha_{0}^{b}-\alpha r_{t-2}+\rho u_{t-3}$. The new information contained in the announcement of $m_{t-2}$ is then equal to

$$
m_{t-2}-E\left(m_{t-2} \mid \Phi_{t}^{b}\right)=u_{t-2}-\rho u_{t-3}=\varepsilon_{t-2} \text {. }
$$

The money "surprise", the difference between the announcement on Friday and the public's expectation of $m_{t-2}$, is just the week $t-2$ innovation in the money demand disturbance.

Making use of the policy rule (2), together with (8), it is possible to derive the adjustment in $r_{t}$ which occurs in response to the announcement (details can be found in the appendix):

$$
r_{t}^{a}-r_{t}^{b}=\alpha^{-1}\left[\frac{\rho(1-\lambda)^{2}\left(1-\delta_{1}\right)\left[(1-\lambda)^{n-1}-1\right]}{1-(1-\lambda)^{n}}+\frac{\left(1-\rho^{n-1}\right)}{1-\rho^{n}} \rho^{3}-\frac{(n-1) \delta_{1} \rho}{n}\right] \varepsilon_{t-2} .
$$

Al though the money surprise, $\varepsilon_{t-2}$, is itself direct information only on the week t-2 money demand innovation, its effect on $r_{t}$ can be seen from (10) to consist of three components. The last term, $\alpha^{-1}(1-n) \delta_{1} \rho / n<0$ is a Keynesian liquidity effect. To the extent that a positive deviation above target, for example, is partially accomnodated $\left(0<\delta_{1}<1\right)$, the money supply will be permanently higher. Since the interest elasticity of the demand for money is negative, interest rates must fall.

The middle term in (10) is positive and represents the effect on $r_{t}$ of the public's revised expectations about future money demand. If $\varepsilon_{t-2}>0$, 
individuals revise upwards their estimates of future $u_{t+i}$ 's. Higher estimates of future money demand lead to expectations of higher future interest rates for a given target path.

The first term in (10), is negative since $(1-\lambda)^{\mathrm{n}-1}<1$. The upward pressure on interest rates produced by a positive surprise is moderated to the extent that the Federal Reserve is expected to return $m$ to the target path only gradually. $\frac{15}{} /$

The effect of the money announcement in this policy anticipations model on interest rates of longer maturity than $r_{t}$ can also easily be derived using the expectations model of the term structure. Let $R_{t}$ be the rate on a security with $m \cdot n$ weeks to maturity. Then

$$
R_{t}=(1 / m) \sum_{k=0}^{m-1} E\left(r_{t+k n} \mid \Phi_{t}\right)
$$

Making use of some earlier results, it can be shown that

$$
\begin{aligned}
R_{t}^{a}-R_{t}^{b}= & (1 / m)\left(r_{t}^{a}-r_{t}^{b}\right)+(1 / m) \alpha^{-1} \sum_{k=1}^{m-1}\left[(1-\lambda)^{k n+1}\left(1-\delta_{1}\right)+\rho^{k n+1}\right] \rho \varepsilon_{t-2} \\
& +[(1-m) / m] \alpha^{-1} \delta_{1} p \varepsilon_{t-2}
\end{aligned}
$$

The first and second terms on the RHS of (12) are both positive if $\varepsilon_{t-2}>0$. The final term is negative, and it represents the money surprise that is permanently accommodated and which, therefore, through a Keynesian liquidity effect, tends to reduce future interest rates. If the Federal Reserve always attempts to return to target, $\delta_{1}=0$ and $\left|R_{t}^{a}-R_{t}^{b}\right|>(1 / m) \cdot\left|\left(r_{t}^{a}-r_{t}^{b}\right)\right|$. Post-October 1979 Operating Procedures

Equations (10) and (12) give the response to the money announcement of both short- and long-term interest rates under a federal funds rate operating 
procedure. On October 6, 1979, however, the Federal Reserve shifted to a nonborrowed reserves operating procedure. Such a procedure involves setting a path for nonborrowed reserves which is consistent with achieving the targeted path for money. To analyze the interest rate response to a money announcement during the post-0ctober 1979 period it is necessary to note that the current week's funds rate, $i_{t}$, is no longer fixed. A positive money surprise indicates to market participants that the level of required reserves for the current settlement week will be higher than expected. This should lead to a higher funds rate in the remainder of the current week, which through the term structure equation (5), leads to a higher $r_{t}$. To explicitly model this additional effect, it is necessary to incorporate into the model a specification of the market for reserves.

Under lagged reserve accounting, the log of required reserves is given by

$$
\operatorname{lnRR}_{t}=k+m_{t-2}
$$

where $k$ is the $\log$ of the required reserve ratio. For simplicity, it is assumed that ali deposits are subject to the same reserve ratio and that the deposit to money ratio is constant. Assuming excess reserves are zero, equation (13) gives the demand for reserves.

The supply of reserves consists of nonborrowed reserves-taken to be the policy variable in the post-october 1979 period-and borrowed reserves. A rise in the funds rate relative to the discount rate leads to a rise in bank borrowings and a fall in nonborrowed reserves as a fraction of total reserves. This relationship is specified as 


$$
\ln \frac{N B R_{t}}{R R_{t}}=B_{0}-B\left(i_{t}-i_{t}^{d i s}\right)+v_{t}
$$

where $1_{t}^{d i s}$ is the discount rate, and $v_{t}$ is a mean zero, serially uncorrelated disturbance term.

To represent the determination of the policy variable in week $t$, assume

$$
\operatorname{lnNBR} t=1 n N B R_{t}^{T}+\psi_{t}
$$

where $\operatorname{lnNBR}_{t}^{T}$ is the (log) value of nonborrowed reserves consistent with achieving the target path for the money supply and $\psi_{t}$ is a transitory policy deviation from the target. Equation ( $7^{\circ}$ ) replaces (7) in an analysis of the post-0ctober 1979 period. Parallel with the treatment of the pre-October 1979 period, assume that at the beginning of week $t$, the public knows $1 n N R_{t}$ but not its decomposition into $1 \mathrm{nNBR}_{t}^{\mathrm{T}}$ and $\psi_{t}$. Under this operating procedure, the federal funds rate adjusts to equilibrate the reserve market. Equating the demand for reserves to the supply and solving for $i_{t}$ yields

$$
i_{t}=i_{t}^{d i s}+\beta^{-1}\left[k+\beta_{0}+m_{t-2}-1 n N B R_{t}^{T}+v_{t}-\psi_{t}\right] \text {. }
$$

The response of the funds rate to the announcement can be shown to equal

$$
E\left(i_{t} \mid \Phi_{t}^{a}\right)-E\left(i_{t} \mid \Phi_{t}^{b}\right)=B^{-1}\left(m_{t-2}-E\left(m_{t-2} \mid \Phi_{t}^{b}\right)\right)=B^{-1} \varepsilon_{t-2} \text {. }
$$

A positive surprise $\left(\varepsilon_{t-2}>0\right)$ causes an upward revision in expected reserve demand over the remainder of the settlement week, leading to a rise in the funds rate.

To determine the impact under a reserves operating procedure of the announcement, equation (5) can be utilized, along with (16) to derive the response of the short-term interest rate: 


$$
\begin{aligned}
r_{t}^{a}-r_{t}^{b}= & {\left[\frac{1}{\beta n}-\frac{\alpha^{-1} \rho(1-\lambda)^{2}\left(1-\delta_{1}\right)\left[(1-\lambda)^{n-1}-1\right]}{1-(1-\lambda)^{n}}\right.} \\
& \left.+\frac{\alpha^{-1}\left(1-\rho^{n-1}\right)^{3}}{1-\rho^{n}}-\frac{\alpha^{-1}(n-1) \delta_{1} \rho}{n}\right] \varepsilon_{t-2}
\end{aligned}
$$

One result is immediate from a comparison of (10), the pre-October 1979 effect, and (17), the post-October 1979 effect. For given values of $\alpha, \rho, \lambda$, and $\delta_{1}$, the change in operating procedures introduces a new term, $1 / B n>0$, into the response coefficient. A given money surprise has a larger effect on short-term interest rates under a nonborrowed reserves operating procedure than under a funds rate operating procedure. This is consistent with the increased response after October 1979 documented in Table 1. From (12) and (17), however, it may be shown that the response of longer term (m-quarter) yields increases by only $1 / \mathrm{m} \cdot 1 / \mathrm{Bn}$. Thus, some other factors in the model must contribute to the increased response of long-term yields.

One possibility is that the change in operating procedures was viewed by the public as accompanied by a shift in the policy adjustment rule followed by the Federal Reserve. If the use of nonborrowed reserves rather than the funds rate was interpreted as signaling a greater determination on the part of the Federal Reserve to keep money on target, either $\lambda$ or $\delta_{1}$ (or both) may have changed. A fall in $\delta_{1}$ would indicate that less of any deviation from target would be accommodated, while a rise in $\lambda$ would indicate a faster elimination of any deviations. Either such change tends to increase the response to the money surprise in (17) and (12).

Another result of the change in operating procedures was a large increase in the volatility generally of interest rates. In Walsh $(1982,1983)$, it is 
shown that a rise in the volatility of interest rates may lead to a fall in the interest elasticity of the demand for money which is proportional to the rise in volatility. Such a decline in $\alpha$ as a consequence of the shift to a nonborrowed reserves operating procedure would also tend to increase the response of both short- and long-term yields to a given money surprise. The effects of changes in these various parameters are examined further using numerical examples in the fourth section.

\section{Expected Inflation Model}

The model in the previous section, in order to focus on the policy anticipations effect, assumed that the expected rate of inflation remained constant in the face of the money announcement. This implies that the interest rate adjustments were adjustments in real interest rates. An alternative view of interest rate determination argues that real interest rates are independent of monetary influences so that any response of interest rates to a money announcement must be due to changes in the expected inflation premium incorporated in market rates. The present section develops a model of interest rate responses which attributes all changes in rates to changes in expected inflation.

If $\mu$ is the constant ex ante real rate of interest and $r_{t}$ is, as before, the rate on an n-week security, then

$$
r_{t}=\mu+\frac{\gamma}{n}\left[E\left(P_{t+n} \mid \Phi_{t}\right)-P_{t}\right]+n_{t}
$$

where $\gamma=5200^{16 /}$ and $\eta_{t}$ is a mean zero disturbance term assumed to be serially uncorrelated.

In the model of section II, any deviation of the money stock from its target value leads to an adjustment in target levels but no change in the targeted long-run growth rate. This assumption needs to be modified to allow for the possibility that a value of $\mathrm{m}_{\mathrm{t}-2}$ above target leads the Federal Reserve to revise 
upwards its targeted growth rate. If this occurred, the public, in the face of a positive money surprise, might infer faster money growth and higher inflation in the future. This possibility can be captured by rewriting the policy reaction rule in the form

$$
\begin{gathered}
\mathrm{m}_{\mathrm{t}+\mathrm{j}}^{\mathrm{T}}\left(\Omega_{\mathrm{t}}\right)-\mathrm{m}_{\mathrm{t}+\mathrm{j}}^{\mathrm{T}}\left(\Omega_{\mathrm{t}-1}\right)= \\
\quad\left[(j+1) \delta_{2}+\delta_{1}+(1-\lambda)^{j+1}\left(1-\delta_{1}\right)\right] \rho \varepsilon_{t-2} ; \\
j=0,1, \ldots
\end{gathered}
$$

where use has been made of the fact that $\rho \varepsilon_{t-2}=E\left(m_{t-1} \mid \Omega_{t}\right)-m_{t-1}^{T}\left(\Omega_{t-1}\right)$. To understand the role of $\delta_{2}$, suppose that the targeted growth rate is $k$ and that $\mathrm{m}_{t+j}^{\mathrm{T}}=\mathrm{m}_{t-2}^{\mathrm{T}}+(j+2) k$. The actual growth rate from $t-2$ to $t-1$ is estimated, at time $t$, to be $k+\rho \varepsilon_{t-2}$. If this growth rate were to be maintained, the new target for $m_{t+j}$ would be $m_{t+j}^{T}=E\left(m_{t-1} \mid \Omega_{t}\right)+(j+1) k+(j+1) \rho \varepsilon_{t-2}$ (ignoring $\lambda$ and $\delta_{1}$ for simplicity). If the deviation has no effect on the targeted growth rate, $\mathrm{m}_{t+j}^{\mathrm{T}}=E\left(\mathrm{~m}_{t-1} \mid \Omega_{t}\right)+(j+1)_{k}$, which is the case considered in the previous section. Equation $\left(2^{\prime}\right)$ allows a fraction $\delta_{2}$ of the growth-rate deviation to have a permanent effect on the Federal Reserve's growth-rate target.

To determine the expected rate of inflation as a function of the underlying parameters of the model, it is first necessary to find the equilibrium solution for the $\log$ of the price level. From the money demand equation (3) and the Fisher equation (18):

$$
m_{t}-p_{t}=\alpha_{0}-\alpha\left[\mu+(\gamma / n)\left(E\left(p_{t+n} \mid \Phi_{t}\right)-p_{t}\right)\right]+u_{t} .
$$

Solving for $\mathrm{p}_{t}$, equation (19) implies

$$
p_{t}=(n+\gamma \alpha)^{-1}\left[n m_{t}+n\left(\alpha \mu-\alpha_{0}\right)+\gamma \alpha E\left(p_{t+n} \mid \Phi_{t}\right)-n u_{t}\right] \text {. }
$$

Since $\gamma \alpha /(n+\gamma \alpha)<1$, equation $(20)$ can be solved forward under the assumption of rational expectations. This yields 


$$
\begin{aligned}
p_{t}= & \alpha \mu-\alpha_{0}+\frac{n}{n+\gamma \alpha}\left(m_{t}-u_{t}\right)+\frac{n}{n+\gamma \alpha} \sum_{j=1}^{\infty}\left(\frac{\gamma \alpha}{n+\gamma \alpha}\right)^{j} E\left(m_{t+j n}^{T} \mid \Phi_{t}\right) \\
& -\frac{n}{n+\gamma \alpha} \sum_{j=1}^{\infty}\left(\frac{\gamma \alpha}{n+\gamma \alpha}\right)^{j} E\left(u_{t+j n} \mid \Phi_{t}\right) .
\end{aligned}
$$

In response to the Friday announcement, $r_{t}$ adjusts to the extent that $(\gamma / n)\left[E\left(p_{t+n} \mid \Phi_{t}\right)-p_{t}\right]$ is affected. Using (21) to evaluate the change in $\left[E\left(p_{t+n} \mid \Phi_{t}\right)-p_{t}\right]$, the appendix shows that under the policy rule $\left(2^{\prime}\right)$,

$$
\begin{aligned}
r_{t}^{a}-r_{t}^{b}= & \gamma\left[\frac{(1-\lambda)^{n+1}\left(1-\delta_{1}\right)}{n+\gamma \alpha\left[1-(1-\lambda)^{n}\right]}-\frac{c^{n+1}}{n+\gamma \alpha\left(1-\rho^{n}\right)}+\frac{n+\gamma \alpha}{n} \delta_{2}\right. \\
& \left.+\frac{1}{n}\left(\delta_{1}+\delta_{2}\right)\right] \rho \varepsilon_{t-2}
\end{aligned}
$$

The corresponding expression for a longer term (m quarter) security is given by

$$
\begin{aligned}
R_{t}^{a}-R_{t}^{b}= & (1 / m)\left(r_{t}^{a}-r_{t}^{b}\right)+\gamma\left[\frac{m-1}{m} \delta_{2}\right. \\
& +(1 / m) \frac{(1-\lambda)^{n+1}\left(1-\delta_{1}\right)\left[1-(1-\lambda)^{-n}\right]}{n+\gamma \alpha\left[1-(1-\lambda)^{n}\right]} \sum_{i=1}^{m-1}(1-\lambda)^{i n} \\
& \left.-(1 / m) \frac{\rho\left(\rho^{n}-1\right)}{n+\gamma \alpha\left(1-\rho^{n}\right)} \sum_{i=1}^{m-1} \rho^{i n}\right] \rho \varepsilon_{t-2} .
\end{aligned}
$$

Letting $m$ go to infinity, equation (23) implies that $\lim _{m \rightarrow \infty}\left(R_{t}^{a}-R_{t}^{b}\right)=\gamma \delta_{2} \rho \varepsilon_{t-2}$; any permanent change in the annual growth rate of money leads to a one-forone rise in long-term interest rates.

Because interest rates in this model adjust only in response to changes in the expected rate of inflation, it is possible to solve for the adjustment responses in (22) and (23) without any reference to the Federal Reserve's operating procedure. The expected inflation model predicts that the interest 
rate response to a money announcement is independent of the particular procedure used by the Federal Reserve to implement monetary policy. To explain the large increases in the response coefficients reported in Table 1 within the context of the inflation expectations model, it is necessary to assume that there were shifts in the basic model parameters at the time of the change in operating procedures. For example, a rise in $\delta_{2}$, the fraction of the week t-2 to t-1 growth rate deviation which the Federal Reserve accommodates, would increase the response coefficients. Using numerical examples, the model is also compared to the estimated responses in the next section.

\section{Evaluation of the Models}

In this section, the stylized models of the policy anticipations and the expected inflation effects are examined in terms of their consistency with the empirical results reported in Table 1 . While the models are specified under a variety of simplifying assumptions, they nevertheless embody the important features of the underlying hypotheses. Following the evaluation of the models, additional empirical evidence is presented on the persistence of announced money surprises.

In examining the consistency of the models with the estimated responses in Table 1, iterative grid searches are performed over the models' parameters in both the pre- and post-October 1979 periods. In addition, the searches are implemented simultaneously for the 3-month $(n=13)$, 1-year $(m=4)$, 5-year $(m=20)$, 10-year $(m=40)$, and the 20-year $(m=80)$ yields. For the policy anticipations model, the response of the 3 -month yield is represented by (10) and (17) for the pre- and post-october 1979 periods, respectively. For longer term yields $(m=4,20,40,80)$, the response under both policy regimes is 
given by (12). For the expected inflation model, the response of the 3-month yield is represented by (22), and the response of longer term yields is given by (23). In each case, all parameters of the models-- $\lambda, \delta_{1}, \alpha, p$, and $\delta_{2}$ (when relevant)--are subjected to the grid search. The criterion used in the search is to minimize the sum of the absolute percentage differences from the point estimates in Table 1 across the five yields. $\underline{17}^{\prime}$ Is the Policy Anticipations Model Consistent with the Estimated Responses?

The response of the term structure of interest rates under the policy anticipations hypothesis is computed for selected parameter values in Table 2. The reported values for the responses consist of both those conforming to the estimated responses in Table 1--given the criterion described above--as well as examples exhibiting the effects of changes in parameter values. As is apparent in the table, sets of parameters are calculated separately for the pre- and post-october 1979 periods.

For the pre-October 1979 period, the policy anticipations model is capable of yielding responses fairly close to those in Table 1 when the parameters take values of $\rho=.986, \alpha=.143, \lambda=.687$, and $\delta_{1}=.000$. The response of the 3-month yield, for example, is calculated as 6.48 , which is identical to its estimated value in Table 1. Moreover, the responses of longer term interest rates are all positive and fairly close to the corresponding estimated values.

The reported parameter values implied by the responses for the preOctober 1979 period suggest that weekly money demand disturbances are highly serially correlated $(\rho=.986)$, and that they are eventually offset completely $\left(\delta_{1}=0\right)$. The speed at which a money demand shock is offset, 
however, is implausibly high. In particular, the value in Table $2(\lambda=.687)$ implies that approximately 68 percent $\left(\lambda \cdot \rho \cdot \varepsilon_{t-2}\right)$ of a surprise in announced money is offset during the week of the announcement. The responses are nevertheless quite insensitive to changes in the rate at which surprises are offset, as indicated by the third and fourth rows in Table 2 . In contrast, the fraction of the surprise accommodated has a larger impact on the responses, as indicated in the second row, where $\delta_{1}$ is increased to .100 .

In the lower panel of Table 2, sets of parameter values for the postOctober 1979 period are reported. The first row again corresponds to the parameters obtained from the grid search. The next three rows report values for selected changes in the policy parameters, as before. The results for the post-October 1979 period suggest that money surprises are somewhat more highly serially correlated $(\rho=.996)$, and that the interest-rate responsiveness of money demand is over five times smaller than that in the pre-October 1979 period.18; Because of the persistence of money demand shocks and the much lower interest-rate responsiveness of money demand, short-term rates must remain above their original levels for an extended period of time if the original long-run target path for money is maintained $\left(\delta_{1}=0\right)$. The combination of these factors is sufficient to explain the relatively large response of longterm interest rates. By comparing the first and fifth rows in each panel, note that changes in policy parameters across periods have negligible effects on the responses.

Is the Expected Inflation Model Consistent with the Estimated Responses? Analogous to Table 2, the response of the term structure of interest rates under the expected inflation hypothesis is solved for selected parameter 
Table 2

SELECTED PARAMETER VALUES FOR

THE POLICY ANTICIPATIONS MODEL*

Policy

Parameters

$\underline{\underline{\delta_{I}}}$

.687 .000

$.687 \quad .100$

$.587 \quad .000$

$.787 \quad .000$

$.779 .000 \neq$

$.779 \quad .000$

$.779 \quad .100$

.679 .000

.879 .000

.687 .000
Interest Rate Response:

\begin{tabular}{|c|c|}
\hline R3M & RIY \\
\hline 6.48 & 5.19 \\
\hline $\begin{array}{l}5.86 \\
5.98\end{array}$ & $\begin{array}{l}4.52 \\
5.07\end{array}$ \\
\hline 6.84 & 5.28 \\
\hline 6.82 & 5.28 \\
\hline 6.48 & 5.20 \\
\hline
\end{tabular}

Interest Rate Response:
Pre-October $1979 \quad(\rho=.986, \alpha=.143)$

\begin{tabular}{|c|c|c|}
\hline R5Y & RIOY & $\mathrm{R} 20 \mathrm{Y}$ \\
\hline 1.96 & 1.006 & .503 \\
\hline 1. 28 & .318 & -.185 \\
\hline 1.94 & .994 & .497 \\
\hline 1.98 & 1.015 & .508 \\
\hline 1.98 & 1.015 & .508 \\
\hline 2.57 & .920 & 1.16 \\
\hline
\end{tabular}

23.8

20.1

23.7

23.9

23.7

21.2
16.1

12.4

16.1

16.1

16.1

16.1

\section{$\alpha=.0265)^{\dagger}$}

35.5
9.06

5.30

9.04

9.08

9.04

14.4

* See the notes in Table 1 for variable definitions. Parameters are defined in the text.

The post-October 1979 responses are calculated under the assumption that the one-week bill yield's response equals its estimated value in Table 1 of 36.72. This estimate implies $B=.027$.

キFrom Table 1 . 
Table 3

SELECTED PARAMETER VALUES FOR

THE EXPECTED INFLATION MODEL*

Policy

Parameters

\begin{tabular}{llll}
\hline & $\delta_{1}$ & $\delta_{2}$ \\
\hline .438 & .006 & .000192 \\
.438 & .000 & .000192 \\
.438 & .106 & .000192 \\
.338 & .006 & .000192 \\
.538 & .006 & .000192 \\
.438 & .006 & .000092 \\
.438 & .006 & .000292 \\
.438 & .021 & .00256 \\
estimatet &
\end{tabular}

Interest Rate Response:

Pre-October $1979(\rho=.931, \alpha=.0418)$

\begin{tabular}{|c|c|c|c|c|}
\hline R3M & RIY & R5Y & $\mathrm{R} 10 \mathrm{Y}$ & $\mathrm{R} 2 \mathrm{OY}$ \\
\hline 6.47 & 5.20 & 1.82 & 1.38 & 1.15 \\
\hline 4.24 & 4.64 & 1.71 & 1.32 & 1.12 \\
\hline 43.7 & 14.5 & 3.68 & 2.31 & 1.62 \\
\hline 6.53 & 5.20 & 1.82 & 1.38 & 1.15 \\
\hline 6.47 & 5.20 & 1.82 & 1.38 & 1.15 \\
\hline-2.14 & 2.69 & .931 & .688 & .567 \\
\hline 15.1 & 7.72 & 2.71 & 2.06 & 1.74 \\
\hline 216 & 66.2 & 23.2 & 17.8 & 15.1 \\
\hline 6.48 & 5.20 & 2.57 & .920 & 1.16 \\
\hline
\end{tabular}

Interest Rate Response:

Post-October $1979(p=.980, \alpha=.0216)$

$\begin{array}{rrrrr}36.4 & 32.3 & 19.1 & 16.1 & 14.6 \\ 28.2 & 30.2 & 18.7 & 15.9 & 14.5 \\ 75.6 & 42.1 & 21.1 & 17.1 & 15.1 \\ 36.5 & 32.3 & 19.1 & 16.1 & 14.6 \\ 36.4 & 32.3 & 19.1 & 16.1 & 14.6 \\ -13.1 & 16.1 & 11.8 & 9.89 & 8.92 \\ 85.9 & 48.5 & 26.4 & 22.3 & 20.2 \\ -86.7 & -7.51 & 1.49 & 1.25 & 1.11 \\ 36.4 & 35.5 & 21.2 & 16.1 & 14.4\end{array}$

* See the notes in Table 1 for variable defintions. Parameters are defined in the text.

†From Table 1. 
values in Table 3. As before, parameter values may be obtained which are consistent with the estimated responses in Table 1. In the pre-0ctober 1979 period, the value for the serial correlation of money demand shocks is again quite high, but the interest-rate responsiveness of money demand is lower than that computed under the policy anticipations hypothesis. The policy parameters also differ substantially. In particular, the rate at which money surprises are of $f$ set ( $\lambda$ ) is .438 , although the reported responses are fairly insensitive to this parameter, as indicated in the fourth and fifth rows in the table. In addition, the results suggest that a portion of the shock is accommodated by changing the level of money's target path $\left(\delta_{1}=.006\right)$, and that the Federal Reserve permanently raises its target growth rate in response to a positive shock $\left(\delta_{2}=.000192\right)$. For a positive 1 percent shock, for example, the target annualized growth rate is increased by almost .01 percentage points $\left(52 \cdot \delta_{2}\right)$. As indicated in the table, the 20-year yield's response of about $I$ basis point predominately reflects this revision in the target growth rate. This sensitivity is also apparent in the sixth and seventh rows in the table, where the responses are calculated with

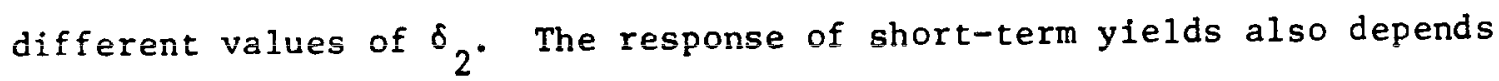
importantly on the initial accommodation in the current level of money $\left(\delta_{1}\right)$, as may be seen in the second and third rows.

For the post-october 1979 period, the two main changes in the parameters are that $\delta_{2}$ increases to .00256 and the interest-rate responsiveness of money demand is about one-half its previous value. As suggested by Cornell (1983) and Hardouvelis (1982), the increase in $\delta_{2}$ indicates greater accommodation of money surprises by the Federal Reserve through revisions in its target growth rate. In this case, the calculated value of $\delta_{2}$ indicates that a 1 percent 
money surprise leads to a revision in the target annualized money growth of .13 percentage points. Again, the 20-year yield's response of 14.6 basis points predominately reflects this accomodation. The eighth row in each panel also indicates the key role of this parameter.

\section{Persistence of Money Surprises}

The previous two subsections indicate that different sets of parameter values may be found that make both the policy anticipations and expected inflation hypotheses consistent with the estimated responses in Table 1 . Despite this inability to distinguish between the hypotheses on the basis of their consistency with the estimated responses, the implications of the models do differ dramatically. In particular, under the policy anticipations hypothesis, the parameter values indicate that money surprises are totally offset af ter some period of time. In contrast, under the expected inflation hypothesis, target growth rates are permanently changed in the direction of the surprise.

These different implications suggest one way in which the hypotheses may be distinguished. In particular, under the policy anticipations hypothesis, past surprises in the announced level of money would be expected to have diminishing effects on the level of the money stock over time. Under the expected inflation hypothesis, this should not be the case. Indeed, for money surprises to affect expected inflation over the maturity of a longterm security, surprises would be expected to persist over lengthy intervals.

The monetary policy rule specified previously $\left(2^{\prime}\right)$ may be used to illustrate the possible relationship between past money surprises and the level of the money stock. In particular, recursive substitution yields

$$
m_{t}=m_{t}^{T}\left(\Omega_{t-k}\right)+\varepsilon_{t}+\rho \varepsilon_{t-1}+\sum_{j=0}^{k-1}\left[(j+1) \delta_{2}+\delta_{1}+(1-\lambda)^{j+1}\left(1-\delta_{1}\right)\right] \rho \varepsilon_{t-j-2}
$$


where $m_{t}=m_{t}^{T}\left(\Omega_{t}\right)+\rho \varepsilon_{t-1}+\varepsilon_{t}$. Under the pure policy anticipations model, $\delta_{2}=0$ so that as $j$ becomes large, the coefficients on the lagged money surprises decline, approaching $\delta_{1} \rho$ asymptotically. In contrast, the inflation expectations model requires $\delta_{2}>0$. In this case, equation (24) shows that as $j$ becomes larger, the coefficients on the lagged money surprises must eventually start increasing with $j$. For the parameters reported in Table 3 for the post-october 1979 period, for example $\left(\lambda=.438, \delta_{1}=.021\right.$, $\left.\delta_{2}=.00256\right)$, the coefficients are increasing for $j \geq 10$.

Equation (24), therefore, suggests a simple means of discriminating between the policy anticipations hypothesis and the inflation expectations hypothesis. To examine the persistence of money surprises, the following empirical analogue of equation (24) is estimated:

$$
m_{t}=b_{0}+b_{1} \cdot \text { trend }_{t}+\sum_{j} c_{j} \varepsilon_{t-j}
$$
where the trend variable is used to proxy $\mathrm{m}_{t}^{\mathrm{T}}\left(\Omega_{t-k}\right) . \frac{19 /}{j}$ If $\delta_{2}>0$, the $c_{j}{ }^{\prime} s$ should eventually increase with $j$; if $\delta_{2}=0$, they should decline towards a possibly nonzero constant. The estimation results for equation (24') for both the pre- and post-october 1979 periods are reported in Table 4 . In each case, the equation is estimated without any constraints on the lag structure. $\frac{20 /}{}$

The estimation results suggest that money surprises are offset within one year. In both periods, additional lag terms were included in the equations until the estimated coefficients appeared to remain around, or even below, zero. 21/ In the pre-October 1979 period, the unconstrained estimates become negative after 33 weeks. Similarly, estimated lag coefficients for the postOctober 1979 period become negative after 48 weeks. This empirical evidence, at least, casts strong doubt on the validity of the expected inflation hypothesis. 
Table is

PERSISIENCE OF MUNEY SUIRTRISES

$\ln y_{t}=b 0+b 1 \cdot t$ tend $t=c 1 \cdot \mathbb{I M}_{t+2-1}+e_{t}$

Pre-october 19791

Post-verober $1979+$

$\begin{array}{lll}b 0 & 5.824 * & (.0126) \\ b 1 & .0011 * & (.0001) \\ c 0 & .9295 * & (.1971) \\ c 1 & .5852 * & (.1996) \\ c 2 & .4850 * & (.2031) \\ c 3 & .3853 & (.2014) \\ c 4 & .3747 * & (.1803) \\ c 5 & .1681 & (.1699) \\ c 6 & .2002 & (.1705) \\ c 7 & .2418 & (.1719) \\ c 5 & .2617 & (.1707) \\ c 9 & .1362 & (.1053) \\ c 10 & .1902 & (.1654) \\ c 11 & .2051 & (.1622) \\ c 12 & .1784 & (.1611) \\ c 13 & .3011 & (.1610) \\ c 14 & .2804 & (.1594) \\ c 15 & .2819 & (.1600) \\ c 16 & .3998 * & (.1649) \\ c 17 & .4098 * & (.1622) \\ c 18 & .4193 * & (.1609) \\ c 19 & .3889 * & (.1609) \\ c 20 & .4344 * & (.1626) \\ c 21 & .4143 * & (.1621) \\ c 22 & .4265 * & (.1586) \\ c 23 & .3270 & (.1690) \\ c 24 & .2866 & (.1736) \\ c 25 & .4550 * & (.1746) \\ c 26 & .3647 * & (.1764) \\ c 27 & .3965 * & (.1797) \\ c 28 & .3590 * & (.1767) \\ c 29 & .3869 * & (.1846) \\ c 30 & .2728 & (.1825) \\ c 31 & .1401 & (.1903) \\ c 32 & .1400 & (.1912) \\ c 33 & .0406 & (.1980) \\ c 34 & -.1059 & (.1916) \\ c 36 & -.1093 & (.1896) \\ c 35 & & \end{array}$

$6.425 * \quad(.0880)$

$\begin{array}{rr}-.0229 * & (.0040) \\ .8443 * & (.0688) \\ .6480 * & (.0603)\end{array}$

$.6362 * \quad(.0695)$

$.5532 * \quad(.0105)$

$.4750 * \quad(.0710)$

.$\therefore 312 * \quad(.0498)$

$.5236 * \quad(.0680)$

$.4739 * \quad(.0690)$

$.5310 * \quad(.0487)$

$.49 \div 6 * \quad(.0685)$

$.4512 * \quad(.0711)$

$.5121 * \quad(.0737)$

$.4483 * \quad(.0747)$

$.6404 * \quad(.0725)$

$.6337 * \quad(.0753)$

$.5663 * \quad(.0754)$

$.4610 * \quad(.0797)$

$.4692 \star \quad(.0768)$

$.4846 * \quad(.0787)$

$.4126 * \quad(.0770)$

$.4500 \pi \quad(.0782)$

$.4084 * \quad(.0780)$

$.5655 * \quad(.0781)$

$.4868 * \quad(.0786)$

$.4136 * \quad(.0777)$

$.3803 * \quad(.0786)$

$.5154 * \quad(.0767)$

$.4305 * \quad(.0770)$

$.2646 * \quad(.0796)$

$.3278 * \quad(.0779)$

$.2595 * \quad(.0794)$

$.2673 * \quad(.0776)$

$.1623 * \quad(.0763)$

$.1157 \quad(.0634)$

$.1896 * \quad(.0634)$

$.1935 * \quad(.0640)$

$.2186 * \quad(.0631)$

$.1757 \% \quad(.0627)$

$.1513 * \quad(.0633)$

$.2837 \% \quad(.0624)$

$.1664 * \quad(.0619)$

$.2525 * \quad(.0618)$

$.2273 \% \quad(.0622)$

$.2436 \% \quad(.0619)$

$.1398 \star \quad(.0620)$

$.0874 \quad(.0613)$

$.1152 \quad(.0510)$

$.0506 \quad(.0601)$

$.0496 \quad(.0607)$

$-.0278 \quad(.0599)$

$-.0001 \quad(.0592)$

$\bar{R}=\quad .94$

.000

- Coefficient is moze than cwice lis estimated standard error.

Tsec the mitec in Iable 1. Due to the log Jengths, the estiration perinds befin 36 and 5l weeks, respertively, after the startinf datee of the sample periods reported in Table 1. Thesc reduced estication piluds consis: of 68 and 111 obscrvatinns in the pre- and post-

Hinber 1979 perinds, respectively. The lags art estimated uncenseralned.

ternd, $t+t_{1} \cdot t^{2}+a_{2} \cdot t^{3}+a_{3} \cdot t^{t}$, witerc $1=1.2 .3 \ldots$ and the

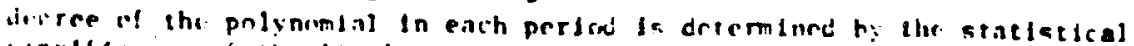

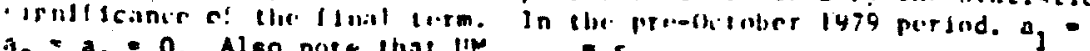

$a_{z}=a_{3}=0$. Also note that $u_{t+2-1}=c_{t-1}$ 


\section{v. Summary of Conclusions}

By constructing a model of interest rate responses to money announcements, it has been possible to examine explicitly the effect of the Federal Reserve's operating procedures and policy rule on the responses across the entire term structure of interest rates. Two main conclusions follow from this paper.

First, despite claims to the contrary, the policy anticipations hypothesis is capable of explaining the response of the entire term structure of interest rates to surprises in weekly money announcements. This hypothesis was shown to be consistent with the response in both the pre- and post-0ctober 1979 periods. Two key elements of this explanation involve the persistence of money demand shocks along with the Federal Reserve's desire to eventually of fset money surprises. Nevertheless, the expected inflation hypothesis was also shown to be consistent with the term structure's response. Under this hypothesis, it follows that the Federal Reserve increases both the level and growth rate of their monetary target in response to positive money surprises.

Second, in examining the effects of past money surprises on the level of the money stock, the empirical evidence suggested that their effects diminish to zero within one year. This result is inconsistent with the expected inflation hypothesis, which posits an increasing effect of money surprises on the level of the money stock. Further empirical work would, nevertheless, be useful in distinguishing between the competing hypotheses. 


\section{Footnotes}

*The authors are associate professor of finance, University of Washington, and assistant professor of economics, Princeton University, respectively. They are grateful to the Federal Reserve Bank of Kansas City for research support, to Rick Troll for research assistance, and to Gikas Hardouvelis, Laurence Kantor, Ryamond Lombra, Douglas Pearce, Howard Roth, David Small, Paul Wachtel, and Charles Webster for helpful comments. This paper is a part of the Financial Markets and Monetary Economics Program of the National Bureau of Economic Research. 1. Initial research on this topic also includes unpublished studies by
Sivesand (1978) and Conrad (1978).

2. Both of these studies are, of course, based on pre-0ctober 1979 data. Using post-October 1979 data, Makin (1982) finds that movements in nominal interest rates have been influenced more by changes in expected real rates
than by expected inflation.

3. However, Cornell (1982) does not attribute these results to the policy anticipations effect. Also, Vrich and wachtel (1982) and Roley and Troll (1983) examine the impact of unanticipated announced changes in the consumer (CPI) and producer (PPI) price indices on Treasury bill yields. Both studies find statistically insignificant responses in the pre-0ctober 1979 period, and lirich and hachtel (1982) estimate a response to PPI surprises which is significant at the 5 percent level in the October 1979-June 1981 period. By extending the sample to October 1982, however, Roley and Troll (1983) finc that the estimated response is again insignificant at the 10
percent level.

4. The excluded observations correspond to announcements of the CPI, the PPI, the unemployment rate, and industrial production. In the pre-October 1979 sample, 43 observations were excluded, while 22 were excluded in the
post-October 1979 sample.

5. Announced changes in MI-B are analyzed here because of the emphasis placed on MI-B by Federal Reserve policymakers and market participants. It should also be noted that the MI-B data for 1981 are not the shift-adjusted M1-B figures which reflect the introduction of nationwide Now accounts. While the Federal Reserve's target range was in terms of shift-adjusted M1-B, weekly announced changes were not shift adjusted.

6. As reported by Roley (1983) in the context of the response of Treasury bill yields, specifying the surprise in terms of levels rather than changes has virtually no effect on the empirical results. For this paper, specifications were estimated with changes in the levels of interest rates, changes in the 108 of interest rates, and with money surprises in terms of announced changes, announced levels, and the log of announced levels. Again these alternative specifications yielded virtually the same results. We are indebted to Raul A. Nicho, vice president with Money Market Services, for making the survey data available for this project. 
7. In forming the revised expectation, the change in the 3-month bill yield from Tuesday at $3: 30$ p.m. to Friday at $3: 30 \mathrm{p} . \mathrm{m}$. is taken as a proxy for the receipt of all new information from the time of the survey to just before the money announcement. Regressing the announced change in money on the survey measure and this change in the bill yield indicates that this proxy is statistically significant at the 5 percent level [see Roley (1983)]. The rationality of the survey data is examined by Grossman (1981) for the preOctober 1979 period and by Roley (1983) for the post-october 1979 period. These studies indicate that except for an additive bias in the pre-0ctober 1979 period, usual hypotheses concerning the rationality of the expected money data used here cannot be rejected at low significance levels. For further analysis of these data, see Urich and Wachtel (1983).

8. In contrast to the other yield data used here, jeral funds rate data provided by the Federal Reserve are in terms of daily averages. These data, however, predominately reflect federal funds trading before $3: 30 \mathrm{p} . \mathrm{m}$.

9. Following Urich and Wachtel (1981) and Roley (1983), more complicated specifications which disaggregated money surprises according to the relationship of money growth to its long-run policy ranges were also estimated. However, because of the larger standard errors of the equations estimated here due to the longer time interval over which the changes in rates were measured, the effects of policy ranges were not statistically significant for any of the yields in the post-october 1979 period. In the pre-October 1979 period, however, the effects of policy ranges were statistically significant in two instances, but only because of statistically significant coefficients with perverse signs. Also, the presence of statistically significant constant terms in some of the estimated equations in Table 1 may reflect measurement error in either the expected money data or the change in interest rates. Alternatively, they may reflect day-of-the-week effects [Gibbons and Hess (1981)].

10. To avoid potential problems associated with heteroscedasticity, the equations in each of the periods are weighted by the reciprocals of their estimated standard errors in the tests.

11. The role of the announcement in providing information on past money demand shifts is emphasized by Urich (1982) and Nichols, Small, and Webster (1983).

12. Equation (2) is similar to the policy rule used by Tinsley, von zur Muehlen, and Fries (1982), although they assume $\delta_{1}=0$.

13. McCallum and Hoehn (1983) analyze the optimal instrument choice in the context of lagged reserve accounting. For empirical evidence, see Sivesand and Hurley (1980).

14. In a similar specification of a biweekly money demand equation, Urich (1982) assumes $u_{t}$ is serially uncorrelated. 
15. Equation (10) can be compared with the results of other authors. Urich (1982) assumes $\varepsilon_{t-2}$ provides no information on $\varepsilon_{t}$ and that $\delta_{1}=0$. His expression for the announcement effect corresponds, therefore, only to the first term in (10). Nichols, Small, and Webster (1983) rely on an expected interest rate change in the money demand equation to motivate future expectations affecting current interest rates. They also assume $m$ is the policy instrument of the Federal Reserve and that $m_{t-2}-E\left(m_{t-2} \mid \Phi_{t}^{b}\right)$ reveals information on the net shock to both money supply and money demand during week t-2. However, under lagged reserve accounting, the major shocks generating week-to-week fluctuations in the money stock arise from the demand for money as modeled here.

16. In the empirical work, interest rates are measured in basis points at annual rates. This makes it necessary to multiply an n-week rate of change such as $\mathrm{p}_{\mathrm{t}+\mathrm{n}}-\mathrm{p}_{\mathrm{t}}$ by 5200 .

17. For computational convenience, certain limitations were placed on the number of digits taken by the parameters. In particular, $\lambda, \delta_{1}$, and $\rho$ were restricted to three decimal points, and three nonzero digits were found for $\alpha$ and $\delta_{2} \cdot$ All parameters were restricted to take values between zero and one.

18. The increased interest-rate volatility in the post-October 1979 period coinciding with the change in operating procedures is capable of explaining this fall in interest elasticity in the model presented by Walsh (1982, 1983). In addition, this elasticity may have declined due to increased financial innovation and deregulation, which may not be totally independent of the rise in volatility. See, for example, Lindsey (1977) and Niehans (1982).

19. Note that a proxy for $\mathrm{m}_{t}^{\mathrm{T}}\left(\Omega_{t-k}\right)$ is not needed in $\left(24^{\prime}\right)$ since the money surprises $\varepsilon_{t-j-2}(j=0, \ldots, k-1)$ are, under rational expectations, uncorrelated with this variable. The proxy was instead included to reduce heteroscedasticity and serial correlation. In this model, as is common in many rational expectations models, standard serial correlation correction procedures would result in inconsistent coefficient estimates. In contrast, OLS estimation yields consistent coefficient estimates in this case, but potentially inconsistent estimated standard errors.

20. Polynomial lags were also estimated, and they yielded virtually the same qualitative results.

21. Extending both lags beyond the lengths reported in Table 4 suggested that the estimated coefficients do not once again increase. Furthermore, lagged money surprises were entered separately on the right-hand side of (24') (i.e., $\left.c_{i}=0(i \neq j), c_{j} \neq 0\right)$ and the estimation results were comparable to those reported in the table. 


\section{$\underline{\text { References }}$}

Berkman, Neil G., "On the Significance of Weekly Changes in Ml," New England Economic Review, (May/June 1978), 5-22.

Conrad, William E., "Initial Treasury Bill Market Response to Money Stock Announcements," mimeo, Board of Governors of the Federal Reserve Systen, 1978.

Cornel1, Bradford, "Money Supply Announcements, Interest Rates, and Foreign Exchange," Journal of International Money and Finance, 1 (August 1982), 201-8.

Cornel1, Bradford, "Money Supply Announcements and Interest Rates: Another View," Journal of Business, 56 (January 1983), 1-24.

Engel, Charles M., and Jeffrey A. Frankel, "Why Money Announcements Move Interest Rates: An Answer from the Exchange Rate Market," National Bureau of Economic Research, Working Paper No. 1049, 1982.

Fama, Eugene F., "Short-Term Interest Rates as Predictors of Inflation," American Economic Review, 65 (June 1975), 269-82.

Gibbons, Michael R., and Patrick J. Hess, "Day of the Week Effects and Asset Returns," Journal of Business, 54 (October 1981), 579-96.

Grossman, Jacob, "The Rationality of Money Supply Expectations and the ShortRun Response of Interest Rates to Monetary Surprises," Journal of Money, Credit, and Banking, 13 (November 1981), 409-24.

Hardouvelis, Gikas A., "Market Perceptions of Federal Reserve Policy and the Weekly Monetary Announcements," mimeo, University of California, Berkeley, 1982 .

Lindsey, David, "The Implications of Removing the Demand Deposit Rate Prohibition for Monetary Control and the Conduct of Monetary Policy," Board of Governors of the Federal Reserve System, Special Studies Paper No. 104, 1977.

Makin, John H., "Effects of Inflation Control Programs on Expected Real Interest. Rates," International Monetary Fund, Staff Papers, 29 (June 1982), 204-32.

McCallum, Bennett T., and James G. Hoehn, "Instrument Choice for Money Stock Control with Contemporaneous and Lagged Reserve Requirements," Journal of Money, Credit, and Banking, 15 (February 1983), 96-101.

Nelson, Charles R., and G. William Schwert, "Short-Term Interest Rates as Predictors of Inflation: On Testing the Hypothesis that the Real Rate of Interest is Constant," American Economic Review, 67 (June 1977), 478-86. 
Nichols, Donald A., David H. Small, and Charles E. Webster, "Why Interest Rates Rise When an Unexpectedly Large Money Stock is Announced," American Economic Review, forthcoming, 1983.

Niehans, Jurg, "Innovation in Monetary Policy," Journal of Banking and Finance, 6 (March 1982), 9-28.

Roley, V. Vance, "Weekly Money Supply Announcements and the Volatility of Short-Term Interest Rates," Federal Reserve Bank of Kansas City, Economic Review, (April 1982), 3-15.

Roley, V. Vance, "The Response of Short-Term Interest Rates to Weekly Money Announcements," Journal of Money, Credit, and Banking, forthcoming, 1983.

Roley, V. Vance, and Rick Troll, "The Impact of New Economic Information on the Volatility of Short-Term Interest Rates," Federal Reserve Bank of Kansas City, Economic Review, (February 1983), 3-15.

Sivesand, Charles, "Fed-Watching and Market Reaction," mimeo, Federal Reserve Bank of New York, 1978.

Sivesand, Charles, and Kevin Hurley, "Choosing an Operating Target for Monetary Policy," Quarterly Journal of Economics, 94 (February 1980), 199-203.

Tinsley, P. A., P. von zur Muehlen, and G. Fries, "The Short-Run Volatility of Money Stock Targeting," Journal of Monetary Economics, 10 (September 1982), 215-37.

Urich, Thomas J., "The Information Content of Weekly Money Supply Announcements," Journal of Monetary Economics, 10 (July 1982), 73-88.

Urich, Thomas J., and Paul Wachtel, "Market Responses to the Weekly Money Supply Announcements in the 1970's," Journal of Finance, 36 (December 1981), 1063-72.

Urich, Thomas J., and Paul Wachtel, "The Effects of Inflation and Money Supply Announcements on Interest Rates," mimeo, New York University, 1982.

Urich, Thomas J., and Paul Wachtel, "The Structure of Expectations of the Weekly Money Supply Announcement," National Bureau of Economic Research, Working Paper No. 1090, 1983.

Walsh, Carl E., "Interest Rate Volatility and Monetary Policy," National Bureau of Economic Research, Working Paper No. 915, 1982.

Walsh, Carl E., "The Effects of Alternative Operating Procedures on Economic and Financial Relationships," in Federal Reserve Bank of Kansas City, Monetary Policy Issues in the 1980s, 1983. 


\section{Appendix}

This appendix contains a more detailed derivation of the results reported in sections II and III.

\section{Policy Anticipations Model}

From the term structure relationship equation (5),

$$
r_{t}=(1 / n) i_{t}+(1 / n) \sum_{i=1}^{n-1} E\left(i_{t+i}^{T} \mid \Phi_{t}\right)
$$

since, from (7), $E\left(i_{t+i} \mid \Phi_{t}\right)=E\left(i_{t+i}^{T} \mid \Phi_{t}\right)$. Using the fact that $(1 / n) \sum_{i=1}^{n-1} E\left(i_{t+i}^{T} \mid \Phi_{t}\right)=$ $E\left(r_{t+1} \mid \Phi_{t}\right)-(1 / n) E\left(i_{t+n} \mid \Phi_{t}\right)$, equation (A.1) can be manipulated to eliminate the future federal funds rates, yielding

$$
r_{t}=(1 / n) i_{t}+\sum_{j=0}^{\infty} E\left(r_{t+j n+1}-r_{t+j n+n} \mid \Phi_{t}\right)+((n-1) / n) E\left(r_{t+\infty} \mid \Phi_{t}\right)
$$

where it is assumed that $E\left(i_{t+\infty}^{T} \mid \Phi_{t}\right)=E\left(r_{t+\infty}^{T} \mid \Phi_{t}\right)$. The target values of $r_{t+i}$ are found by using the money demand equation $\left(3^{-}\right)$:

$$
r_{t+i}^{T}\left(\Omega_{t}\right)=\alpha^{-1} \alpha_{0}-\alpha^{-1} m_{t+i}^{T}\left(\Omega_{t}\right)+\alpha^{-1} E\left(u_{t+i} \mid \Omega_{t}\right) ; i=0, \ldots
$$

Taking expectations of (A.3) and substituting the result into (A.2) implies

$$
\begin{aligned}
r_{t}= & (1 / n) i_{t}-\alpha^{-1} \sum_{j=0}^{\infty} E\left(m_{t+j n+1}^{T}-m_{t+j n+n}^{T} \mid \Phi_{t}\right) \\
& +\alpha^{-1} \sum_{j=0}^{\infty} E\left(u_{t+j n+1}-u_{t+j n+n} \mid \Phi_{t}\right) \\
& +((n-1) / n) E\left(r_{t+\infty}^{T} \mid \Phi_{t}\right) .
\end{aligned}
$$

Equation (A.4) can be used to determine the interest rate response to the announcement:

$$
\begin{aligned}
r_{t}^{a}-r_{t}^{b}=-\alpha^{-1} \sum_{j=0}^{\infty}\left\{E\left(m_{t+j n+1}^{T} \mid \Phi_{t}^{a}\right)-E\left(m_{t+j n+1}^{T} \mid \Phi_{t}^{b}\right)\right. \\
\\
\left.-E\left(m_{t+j n+n}^{T} \mid \Phi_{t}^{a}\right)+E\left(m_{t+j n+n}^{T} \mid \Phi_{t}^{b}\right)\right\}
\end{aligned}
$$




$$
\begin{aligned}
+\alpha^{-1} \sum_{j=0}^{\infty}\left\{E\left(u_{t+j n+1} \mid \Phi_{t}^{a}\right)-E\left(u_{t+j n+1} \mid \Phi_{t}^{b}\right)\right. \\
\left.-E\left(u_{t+j n+n} \mid \Phi_{t}^{a}\right)+E\left(u_{t+j n+n} \mid \Phi_{t}^{b}\right)\right\} \\
+\frac{n-1}{n} \alpha^{-1}\left[E\left(m_{t+\infty}^{T} \mid \Phi_{t}^{a}\right)-E\left(m_{t+\infty}^{T} \mid \Phi_{t}^{b}\right)\right]
\end{aligned}
$$

To evaluate each of these terms, note that equation (2) implies, since $\Phi_{t}^{b}=\Omega_{t-1}$ and $\Phi_{t}^{a}=\Omega_{t}$,

$$
E\left(m_{t+j n+1}^{T} \mid \Phi_{t}^{a}\right)-E\left(m_{t+j n+1}^{T} \mid \Phi_{t}^{b}\right)=\left(\varepsilon_{1}+(1-\lambda)^{j n+2}\left(1-\delta_{1}\right)\right) \rho \varepsilon_{t-2} .
$$

Also, from (4),

$$
E\left(u_{t+j n+1} \mid \Phi_{t}^{a}\right)-E\left(u_{t+j n+1} \mid \Phi_{t}^{b}\right)=\rho^{j n+3} u_{t-2}-\rho^{j n+4} u_{t-3}=\rho^{j n+3} \varepsilon_{t-2} .
$$

Using (A.6) and (A.7), equation (A.5) becomes

$$
\begin{aligned}
r_{t}-r_{t}^{b}= & -\alpha^{-1} \sum_{j=0}^{\infty}\left\{\left[\delta_{1}+(1-\lambda)^{j n+2}\left(1-\delta_{1}\right)\right]-\left[\delta_{1}+(1-\lambda)^{j n+n+1}\left(1-\delta_{1}\right)\right]\right\}_{\rho} \varepsilon_{t-2} \\
& +\alpha^{-1} \sum_{j=0}^{\infty}\left[\rho^{j n+3}-\rho^{j n+n+2}\right] \varepsilon_{t-2}-\frac{n-1}{n} \alpha^{-1} \delta_{1} \rho \varepsilon_{t-2} \\
= & \alpha^{-1}\left[\frac{\rho(1-\lambda)^{2}\left(1-\delta_{1}\right)\left[(1-\lambda)^{n-1}-1\right]}{1-(1-\lambda)^{n}}+\frac{\left(1-\rho^{n-1}\right)}{1-\rho^{n}} \rho^{3}-\frac{(n-1) \delta_{1} \rho}{n}\right] \varepsilon_{t-2} .
\end{aligned}
$$

which is equation (10).

To derive the response for longer term interest rates, equation (11) implies

$$
R_{t}^{a}-R_{t}^{b}=(1 / m)\left(r_{t}^{a}-r_{t}^{b}\right)+(1 / m) \sum_{k=1}^{m-1}\left[E\left(r_{t+k n} \mid \Phi_{t}^{a}\right)-E\left(r_{t+k n} \mid \Phi_{t}^{b}\right)\right]
$$

lising (A.3), since $E\left(r_{t+k n} \mid \Phi_{t}\right)=E\left(r_{t+k n}^{T} \mid \Phi_{t}\right)$,

$$
R_{t}^{a}-R_{t}^{b}=(1 / m)\left(r_{t}^{a}-r_{t}^{b}\right)+(1 / m) \sum_{k=1}^{m-1}\left[-\alpha^{-1}\left[E\left(m_{t+k n}^{T} \mid \Phi_{t}^{a}\right)-\right.\right.
$$




$$
\left.E\left(m_{t+k n}^{T} \mid \Phi_{t}^{b}\right)\right]+\alpha^{-1}\left[E\left(u_{t+k n} \mid \Phi_{t}^{a}\right)-E\left(u_{t+k n} \mid \Phi_{t}^{b}\right)\right]
$$

From (A.6) and (A.7), equation (A.9) can be rewritten as

$$
\begin{aligned}
R_{t}^{a}-R_{t}^{b}= & (1 / m)\left(r_{t}^{a}-r_{t}^{b}\right)+(1 / m) \alpha^{-1} \sum_{k=1}^{m-1}\left[(1-\lambda)^{k n+1}\left(1-\delta_{1}\right)+\rho^{k n+1}\right]_{\rho \varepsilon_{t-2}} \\
& +[(1-m) / m] \alpha^{-1} \delta_{1} \rho \varepsilon_{t-2}
\end{aligned}
$$

This is equation (12).

For the post-october 1979 operating procedures, $i_{t}$ does not necessarily remain constant in response to the announcement. From (A.4), this implies that a term, $(1 / n)\left[E\left(i_{t} \mid \Phi_{t}^{a}\right)-E\left(i_{t} \mid \Phi_{t}^{b}\right)\right]$ must be added to (A.5). From (15),

$$
E\left(i_{t} \mid \Phi_{t}^{a}\right)-E\left(i_{t} \mid \Phi_{t}^{b}\right)=B^{-1}\left(m_{t-2}-E\left(m_{t-2} \mid \Phi_{t}^{b}\right)\right)=B^{-1} \varepsilon_{t-2} .
$$

adding $(1 / n) B^{-1} \varepsilon_{t-2}$ to the response coefficient found in (10) yields (17). Expected Inflation Model

From the Fisher relationship, equation (18),

$$
r_{t}^{a}-r_{t}^{b}=(\gamma / n)\left[E\left(p_{t+n} \mid \Phi_{t}^{a}\right)-E\left(p_{t+n} \mid \Phi_{t}^{b}\right)\right]
$$

The solution equation for $p_{t}$, given by (21), implies that

$$
\begin{aligned}
P_{t+n}= & \alpha \mu-\alpha_{0}+\frac{n}{n+\gamma \alpha}\left(m_{t+n}-u_{t+n}\right) \\
& +\frac{n}{n+\gamma \alpha} \sum_{j=1}^{\infty}\left(\frac{\gamma \alpha}{n+\gamma \alpha}\right)^{j} E\left(m_{t+n+j n}^{T} \mid \Phi_{t}\right) \\
& -\frac{n}{n+\gamma \alpha} \sum_{j=1}^{\infty}\left(\frac{\gamma \alpha}{n+\gamma \alpha}\right) j_{E}\left(u_{t+n+j n} \mid \Phi_{t}\right)
\end{aligned}
$$

Taking expectations of both sides of (A.12) yields

$$
\begin{aligned}
E\left(p_{t+n} \mid \Phi_{t}\right)= & \alpha \mu-\alpha_{0}+\frac{n}{n+\gamma \alpha} \sum_{j=1}^{\infty}\left(\frac{\gamma \alpha}{n+\gamma \alpha}\right)^{j-1} E\left(m_{t+j n}^{T} \mid \Phi_{t}\right) \\
& -\left(\frac{n}{n+\gamma \alpha}\right) \sum_{j=1}^{\infty}\left(\frac{\gamma \alpha}{n+\gamma \alpha}\right)^{j-1} E\left(u_{t+j n} \mid \Phi_{t}\right) .
\end{aligned}
$$


From (A.11) and (A.13) it follows that

$$
\begin{aligned}
r_{t}^{a}-r_{t}^{b}= & (\gamma / n)\left\{\frac{n}{n+\gamma \alpha} \sum_{j=1}^{\infty}\left(\frac{\gamma \alpha}{n+\gamma \alpha}\right)^{j-1}\left[E\left(m_{t+j n}^{T} \mid \Phi_{t}^{a}\right)-E\left(m_{t+j n}^{T} \mid \Phi_{t}^{b}\right)\right]\right. \\
& \left.-\frac{n}{n+\gamma \alpha} \sum_{j=1}^{\infty}\left(\frac{\gamma \alpha}{n+\gamma \alpha}\right)^{j-1}\left[E\left(u_{t+j n} \mid \Phi_{t}^{a}\right)-E\left(u_{t+j n} \mid \Phi_{t}^{b}\right)\right]\right\} .
\end{aligned}
$$

When $\left(2^{\circ}\right)$ is the policy rule,

$$
E\left(m_{t+j}^{T} \mid \Phi_{t}^{a}\right)-E\left(m_{t+j}^{T} \mid \Phi_{t}^{b}\right)=\left[(j+1) \delta_{2}+\delta_{1}+(1-\lambda)^{j+1}\left(1-\delta_{1}\right)\right] \rho \varepsilon_{t-2} \cdot
$$

Using (A.15) and (A.7), equation (A.14) can be written as

$$
\begin{aligned}
r_{t}^{a}-r_{t}^{b}= & \gamma\left[\frac{(1-\lambda)^{n+1}\left(1-\delta_{1}\right)}{n+\gamma \alpha\left[1-(1-\lambda)^{n}\right]}-\frac{\rho^{n+1}}{n+\gamma \alpha\left(1-\rho^{n}\right)}+\frac{n+\gamma \alpha}{n} \delta_{2}\right. \\
& \left.+\frac{1}{n}\left(\delta_{1}+\delta_{2}\right)\right] \rho \varepsilon_{t-2} .
\end{aligned}
$$

This is equation (22).

To find the response of long-term interest rates, start with equation (A.8). From the Fisher equation,

$$
E\left(r_{t+k n} \mid \Phi_{t}^{a}\right)-E\left(r_{t+k n} \mid \Phi_{t}^{b}\right)=(\gamma / n)\left[E\left(p_{t+k n+n} \mid \Phi_{t}^{a}\right)-E\left(p_{t+k n+n} \mid \Phi_{t}^{b}\right)\right]
$$

Using (A.13), (A.15), and (A.7), equation (A.8) under the inflation expectations model yields equation (23):

$$
\begin{aligned}
R_{t}^{a}-R_{t}^{b}= & (1 / m)\left(r_{t}^{a}-r_{t}^{b}\right)+\gamma\left[\frac{m-1}{m} \delta_{2}\right. \\
& +(1 / m) \frac{(1-\lambda)^{n+1}\left(1-\delta_{1}\right)\left[1-(1-\lambda)^{-n}\right]}{n+\gamma \alpha\left[1-(1-\lambda)^{n}\right]} \sum_{i=1}^{m-1}(1-\lambda)^{i n} \\
& \left.-(1 / m) \frac{\rho\left(\rho^{n}-1\right)}{n+\gamma \alpha\left(1-\rho^{n}\right)} \sum_{i=1}^{m-1} \rho^{i n}\right] \rho \varepsilon_{t-2} .
\end{aligned}
$$

